\title{
Effect of ioglycamide (Biligram) on bile flow and biliary lipid secretion in $\operatorname{man}^{1}$
}

\author{
G. D. BELL, J. DORAN, M. FAYADH, G. MURPHY, AND R. H. DOWLING \\ From the University Department of Therapeutics, City Hospital, Nottingham, and the Gastroenterology \\ Units of St. Bartholomew's Hospital and Guy's Hospital Medical School, London
}

SUMMARY Twenty-one anicteric patients with a t-tube in situ were studied between the ninth and 11 th postoperative days. Eleven patients were given an intravenous infusion of the biliary contrast agent ioglycamide (Biligram), while the other 10 acted as controls. Bile flow was recorded and the biliary concentrations of ioglycamide, bile salt, phospholipid, and cholesterol estimated in the two groups. The biliary excretion of ioglycamide was associated with a significant choleresis which was probably due to the obligatory coupling of the osmotically active contrast agent molecules with water. Biliary ioglycamide excretion did not significantly alter bile salt secretion rates. In contrast, the biliary secretion of both phospholipid and cholesterol was significantly lowered $(\mathrm{P}<0.001)$. Unlike chenodeoxycholic acid, ioglycamide significantly reduced bile acid independent cholesterol secretion $(\mathbf{P}<0.01)$, although secretion rate in terms of $\mu \mathrm{mol}$ of cholesterol per $\mu \mathrm{mol}$ of bile acid was essentially unchanged.

The biliary secretion of phospholipids and cholesterol is partially dependent on the simultaneous secretion of bile acid (Entenman et al., 1969; Hardison and Francis, 1969; Nilsson and Schersten, 1970; Dowling et al., 1971; Northfield and Hofmann, 1973), but the mechanism involved for this biliary lipid coupling is poorly understood. Small (1970) suggested that during their transit across the hepatocyte the bile acids might penetrate the canalicular membrane from the interior of the cell and specifically leech out lecithin (the main phospholipid found in bile) and cholesterol, leaving the membrane protein and other structural lipids intact. Several groups (Swell et al., 1968; Hardison and Francis, 1969; Young, 1971), on the other hand, have suggested that a specific macromolecular complex of bile acid, lecithin, cholesterol, and water is assembled inside the hepatocyte before being excreted into bile.

It is now known that biliary cholesterol secretion is much less influenced by changes in bile acid secretion than is phospholipid excretion. This helps to

i Presented in part at the spring meeting of the British Society of Gastroenterology, Cambridge, 1977 (Bell, G. D., Doran, J., Fayadh, M., Murphy, G., and Dowling R. H. (1977). Effect of ioglycamide (Biligram) on bile flow and biliary lipid secretion in man. Gut, 18, A403).

Received for publication 26 October 1977 explain why human bile becomes saturated with cholesterol - that is, 'lithogenic'-at low bile acid secretion rates (Grundy et al., 1972; Northfield and Hofmann, 1973). Oral chenodeoxycholic acid (CDCA) is an effective treatment for cholesterol gallstones (Danzinger et al., 1972; Bell et al., 1972b) because it 'uncouples' the normal bile acid/cholesterol relationship in bile with the result that the patient's bile is less than saturated with cholesterol even at low bile acid outputs (Northfield et al., 1975). Any other compound like CDCA that is shown to affect bile acid/cholesterol coupling would be of interest, because $(a)$ it might shed light on our understanding of the physiology of biliary lipid secretion, and (b) might have implications in the future development of other cholesterol gallstone dissolving drugs.

In the rhesus monkey it was found that the intravenous cholangiographic agent ioglycamide (Biligram, Schering Chemicals Ltd.) was not only a potent choleretic (Whitney and Bell, 1976) but at the same time it significantly $(P<0.01)$ enhanced the ratio of bile salts + phospholipid/cholesterol in bile (Bell and Dowling, unpublished results). During studies of the biliary excretion of ioglycamide at different infusion rates (Bell et al., 1978a) we decided also to examine, in man, the effect of this compound on bile flow and biliary lipid output. This paper reports our findings. 


\section{Methods}

\section{PATIENTS}

Twenty-one patients who had undergone cholecystectomy with exploration of the common bile duct for gallstones were studied. They all had common bile duct $t$-tubes through which cholangiograms were performed on the seventh or eighth postoperative day. The t-tubes were then clamped for two to three days to ensure that the enterohepatic circulation of bile salts had been re-established. The serum bilirubin levels of all patients were normal at the time of study. The experiments were started at $9.00 \mathrm{a} . \mathrm{m}$. in the non-fasted state. At the beginning of the study the t-tube was unclamped and the bile allowed to drain by gravity. The first few millilitres of bile were discarded and then two 'baseline' 10-minute bile collections were made before the intravenous infusion of ioglycamide was started. Bile samples were then collected at 10-minute intervals for a further 120 minutes and their volumes recorded. Five patients were given a two-hour intravenous infusion of ioglycamide at a rate of $2 \mathrm{mg} . \mathrm{kg}$ body weight ${ }^{-1} \mathrm{~min}^{-1}$, while six patients received an infusion of ioglycamide at $4 \mathrm{mg} . \mathrm{kg}$ body weight ${ }^{-1}$ $\mathrm{min}^{-1}$ for one hour, followed by $1 \mathrm{mg} . \mathrm{kg}$ body weight ${ }^{-1} \mathrm{~min}^{-1}$ for a further 30 minutes. The intravenous infusions were controlled by a constant infusion pump (Ivac 531, Ivac Corporation, Harrow, Middlesex). The remaining 10 patients received no ioglycamide and acted as controls. All 21 patients were encouraged to drink liberal quantities of water throughout the period of study. Informed consent was obtained in every case.

\section{BILE ANALYSIS}

The bile samples were stored at $-20^{\circ} \mathrm{C}$. The specimens were thawed and thoroughly shaken before taking the various aliquots for analysis (Bell et al., 1972a). Total bile acid concentration was measured enzymatically using Admirand and Small's (1968) modification of the method of Talalay (1960). The cholesterol content of the bile samples was assayed by an enzymatic method (Roda et al., 1975) using the Boehringer Mannheim Kit (Boehringer Ltd., England). Biliary phospholipid was measured using the method of Bartlett (1959). Biliary ioglycamide levels were estimated using a spectrophotometric method (Bell et al., 1978b).

\section{STATISTICAL ANALYSIS}

In each of the 21 patients, 14 consecutive 10-minute bile samples were taken for analysis. In each 10-minute period the bile flow $(\mathrm{ml} / \mathrm{min})$ and biliary secretion rate $(\mu \mathrm{mol} / \mathrm{min})$ of ioglycamide, bile salt, phospholipid, and cholesterol was estimated. In each sample the following ratios were also calculated: (1) the bile salt plus phospholipid/cholesterol (BS + $\mathrm{PL} / \mathrm{C}$ ) and (2) phospholipid/cholesterol (PL/C). In addition, the secretion rates of bile salts, phospholipids, and cholesterol were also expressed as a percentage of their baseline values (baseline secretion being arbitrarily defined as the average of the first two 10-minute samples). Then, for each of the above variables and ratios, the mean values for the 10 control subjects were compared with those for the 11 patients given intravenous ioglycamide. The significance of difference found was assessed using an unpaired Student's $t$ test.

In each individual patient the relationships between bile salt secretion rate (plotted on the ordinate or $\mathrm{x}$ axis) and (a) bile flow (y data) and (b) biliary cholesterol excretion (y data) were studied. The excretion rates of water and cholesterol and their respective correlation coefficient $(r)$ were calculated from the regression equation $y=m x+b$, where $b$ represents the $y$ intercept, $m$ is the slope of the regression line. The mean values for both $b$ and $\mathrm{m}$ were calculated for the 10 controls and the 11 ioglycamide treated patients and the significance of any differences found assessed by an unpaired Students $t$ test. In addition, the relationship between biliary ioglycamide secretion (x data) and bile flow (y data) was calculated for each of the 11 patients given ioglycamide using the above regression equation. The mean slope and mean intercept relating ioglycamide output and bile flow was then calculated.

\section{Results}

BILIARY EXCRETION OF IOGLYCAMIDE

It can be seen from Fig. 1 that significant amounts of ioglycamide begin to appear in the bile 20 minutes after the start of the intravenous infusion. The rate of biliary excretion of the contrast agent was very similar in the two different intravenous infusion groups. For this reason we have combined the results of the two infusion groups and for the rest of this paper all 11 patients will be referred to as the 'ioglycamide treated group'.

\section{EFFECT OF IOGLYCAMIDE ON BILE FLOW}

The excretion of ioglycamide into bile was associated with a significant choleresis (Fig. 2). There was a statistically significant relationship between bile salt secretion and bile flow in each of the 10 control patients and nine of the 11 ioglycamide treated group. The mean $( \pm$ SEM) slope $m$ of the 10 controls of $0.028 \pm 0.009$ (range 0.008-0.078) was not significantly different from that of the 11 ioglycamide treated patients $(0.009 \pm 0.001$-range 0.002-0.018). In contrast, the mean intercept $b$ - that is, bile salt 


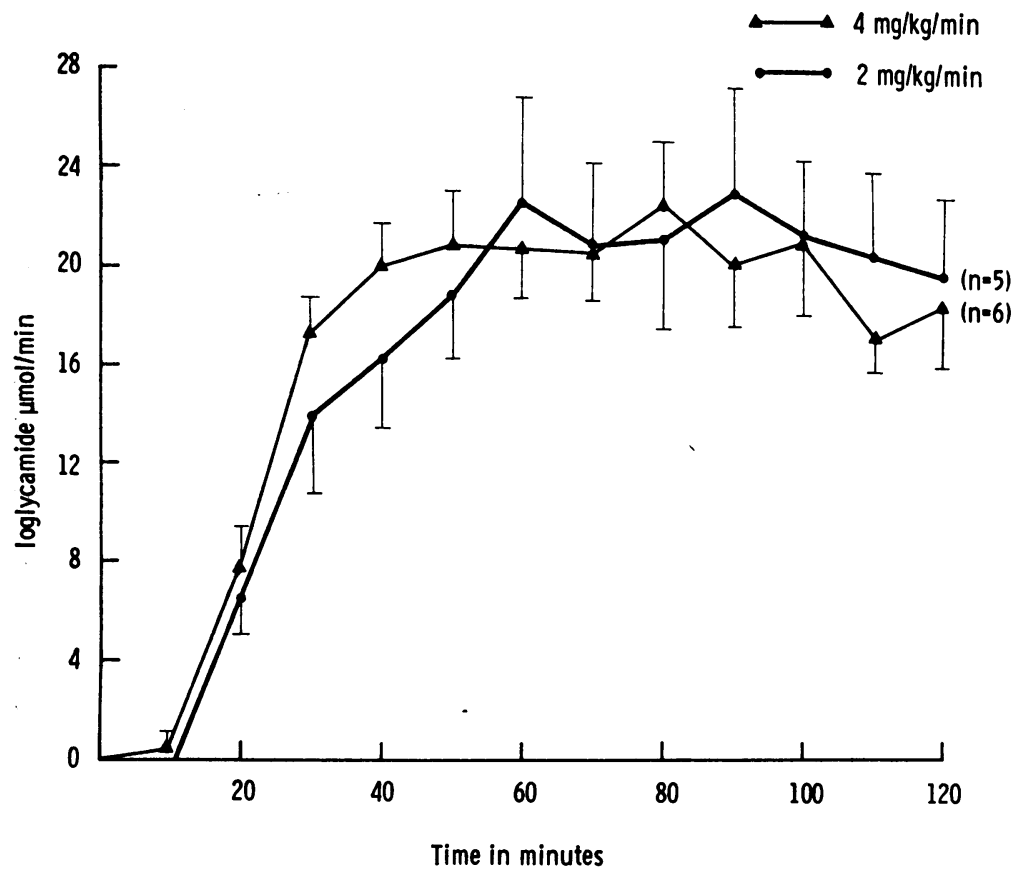

Fig. 1 Biliary excretion of ioglycamide ( $\mu \mathrm{mol} / \mathrm{min})$ following intravenous administration of the contrast agent at either 2 or $4 \mathrm{mg} . \mathrm{kg}$ body weight ${ }^{-1}$ min $^{-1}$ see text.

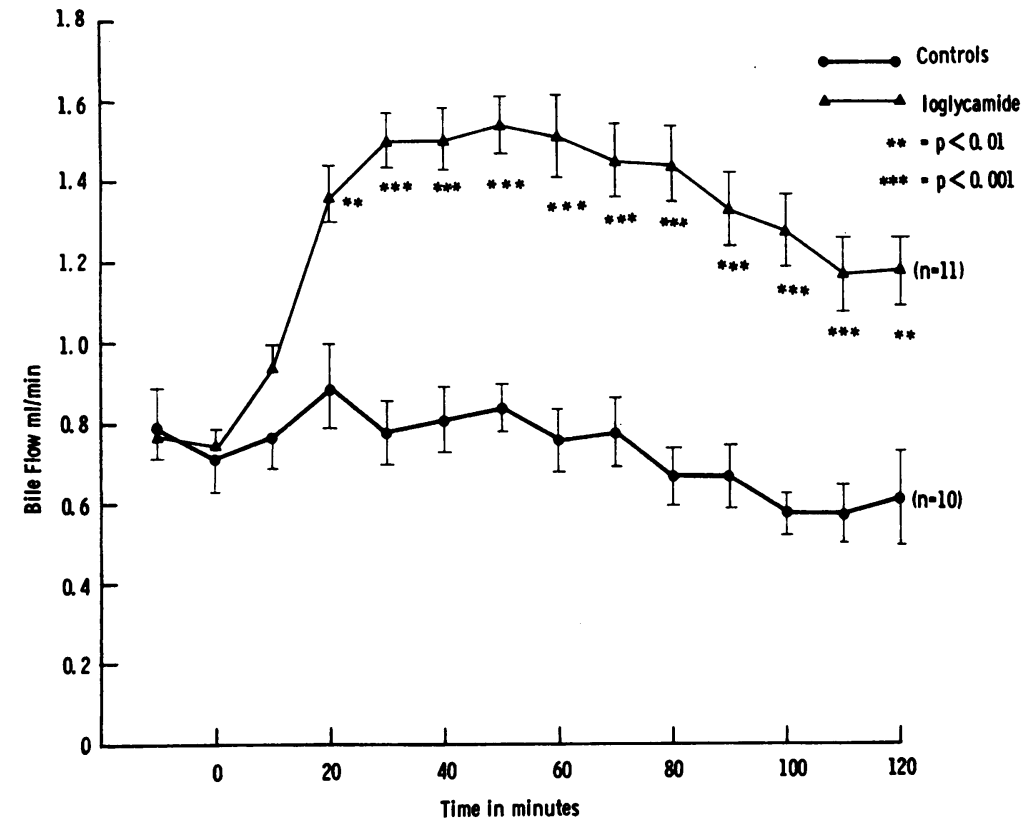

Fig. 2 Effect of ioglycamide on mean bile flow ( $\mathrm{ml} / \mathrm{min})$.

independent bile flow - of the ioglycamide group $1 \cdot 190 \pm 0.103$ (range $0 \cdot 704-1 \cdot 873$ ) was significantly $(P<0.001)$ greater than that of the control group $(0.310 \pm 0.054$, range $0.001-0.608)$.

In 10 of the 11 patients given ioglycamide there was a highly significant $r$ value relating ioglycamide secretion to bile flow. The mean slope ( \pm SEM) was $0.023 \pm 0.002$ with a mean intercept on the bile flow axis of $0.934 \pm 0.049 \mathrm{ml} / \mathrm{min}$. As can be seen from Fig. 1 the ioglycamide secretion reached peak levels about one hour after the start of the intravenous infusion and was then maintained for the rest of the 
experiment. The maximum secretion rate of ioglycamide achieved in the individual patients ranged from $11 \cdot 4-38 \cdot 1 \mu \mathrm{mol} / \mathrm{min}$. There was not a statistically significant relationship between baseline bile salt secretion rate and the maximum ioglycamide secretion rate achieved in the individual patient.

\section{EFFECT OF IOGLYCAMIDE ON BILE SALT SECRETION}

The baseline bile salt secretion rate was slightly higher in the ioglycamide treated group than in the controls, but this difference was not statistically significant. In both groups the bile salt secretion rates remained relatively constant for a further 60 minutes, and then gradually fell as the bile salt pool began to be 'washed out'. At no time were there significant differences between the two groups (Fig. 3). Similarly, when bile salt secretion was expressed in terms of percentage of baseline secretion there was once again no significant difference between the ioglycamide infused and control groups.

\section{EFFECT OF IOGLYCAMIDE ON BILIARY}

\section{PHOSPHOLIPID SECRETION}

The mean $( \pm$ SEM) biliary phospholipid secretion rate in the first baseline samples from the control group of $9.25 \pm 1.49 \mu \mathrm{mol} / \mathrm{min}$ was slightly higher than that of the ioglycamide treated group $(7.68 \pm$ $0.69 \mu \mathrm{mol} / \mathrm{min})$. For purposes of comparison, changes in phospholipid secretion were therefore calculated in terms of percentage change in baseline secretion rates. It can be seen from Fig. 4 that within 30 minutes of the start of the of the ioglycamide infusion the phospholipid secretion rate in the treated group began to fall and by 40 minutes phospholipid secretion was significantly depressed. By the end of the experiment phospholipid secretion rate was only $17.7 \pm 5.1 \%$ of baseline values in the ioglycamide group, compared with $72 \cdot 1 \pm 12 \cdot 2 \%$ in the control group $(\mathrm{P}<0.01)$.
EFFECT OF IOGLYCAMIDE ON BILIARY CHOLESTEROL SECRETION

The mean biliary cholesterol secretion rate in the first baseline samples from the control group of $2.80 \pm 0.40 \mu \mathrm{mol} / \mathrm{min}$ was similar to that of the ioglycamide treated group of $2.91 \pm 0.40 \mu \mathrm{mol} / \mathrm{min}$. Figure 5 shows that in the first 30 minutes after starting the ioglycamide infusion the patients secreted more cholesterol into their bile than the control group, but these differences were not significant. The biliary cholesterol output then fell progressively and by 70 minutes was significantly less $(P<0.05)$ in the ioglycamide treated group than the control subjects. By the end of the experiment cholesterol secretion was only $32.3 \pm 5.8 \%$ of baseline values in the ioglycamide group, compared with $81.9 \pm 9.8 \%$ in the control subjects $(P<0.001)$.

RELATIONSHIP BETWEEN BILE SALT SECRETION AND BILIARY CHOLESTEROL OUTPUT:

EFFECT OF IOGLYCAMIDE

Since significant amounts of ioglycamide did not start to appear in bile (Fig. 1) until 20 minutes after the start of the intravenous infusion, only the last 10 samples were used to study the relationship between bile salt secretion and biliary cholesterol output. Table 1 shows the individual correlation coefficients, slopes, and intercepts on the biliary cholesterol axis of all 10 controls and 11 ioglycamide treated patients. The mean slope was very similar in the two groups, but the mean intercept on the biliary cholesterol axis-that is, the bile salt independent fraction of cholesterol flow-was significantly lowered by the ioglycamide infusion $(P<0.01)$.

EFFECT OF IOGLYCAMIDE ON THE

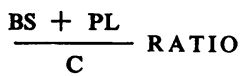

The mean ratio in the two baseline samples was very

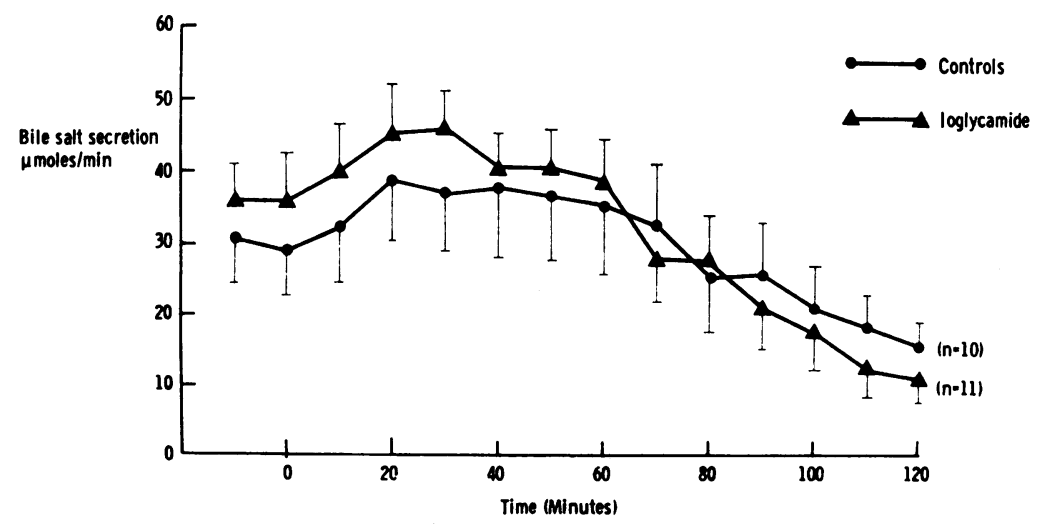

Fig. 3 Effect of ioglycamide on mean bile salt secretion ( $\mu \mathrm{mol} / \mathrm{min}$ ). 


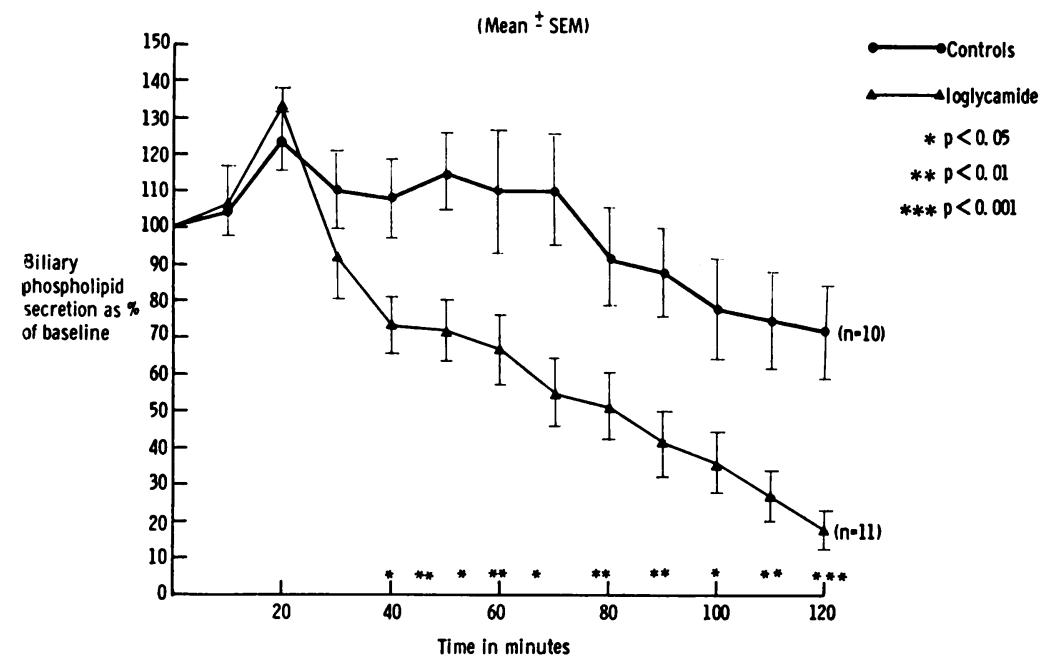

Fig. 4 Effect of ioglycamide on mean biliary phospholipid secretion-phospholipid secretion expressed as percentage of baseline secretion.

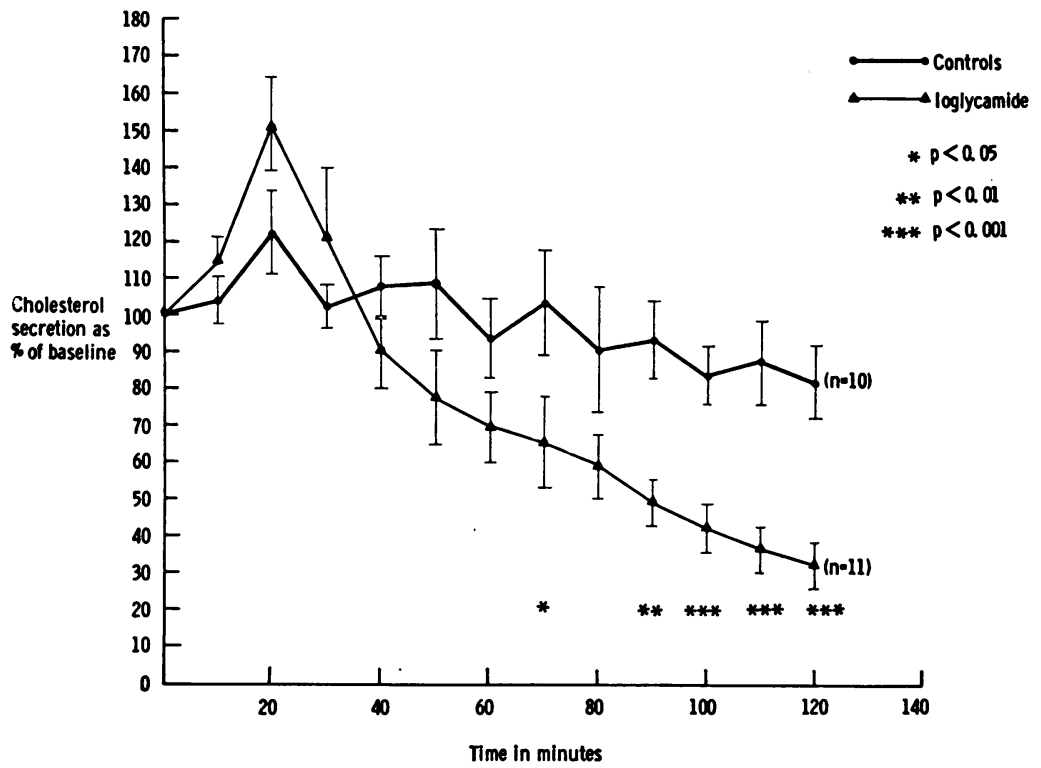

Fig. 5 Effect of ioglycamide on mean biliary cholesterol secretion-cholesterol secretion expressed as percentage of baseline secretion.

similar in the two groups (Table 2). After 50 minutes of intravenous ioglycamide the mean $\frac{B S+P L}{C}$ ratio was $24 \cdot 6 \pm 4 \cdot 3$ compared with $17 \cdot 3 \pm 2 \cdot 4$ in the control group. As can be seen from Table 2, at no stage were the differences in this ratio statistically significant. When, however, the mean ratio of the two baseline specimens was compared with the ratio of the 60 minute specimen using a paired $t$ test the differences did become significant in the ioglycamide treated group $(P<0.02)$, but not in the controls.
EFFECT OF IOGLYCAMIDE ON BILIARY PL/C RATIOS

The mean PL/C ratio in the two baseline samples taken from the 10 controls was slightly higher than that of the ioglycamide group, but this difference was not significant (Table 3). The PL/C ratio remained fairly constant in the control group over the first 100 minutes of study, and then fell slightly over the last 40 minutes of the experiment. The PL/C ratio of the ioglycamide group fell significantly soon after the start of the infusion of biliary contrast material 
and stayed depressed throughout the two hour period of study.

\section{Discussion}

Ioglycamide (Biligram) consists of two iodinated benzene rings joined by a polymethylene chain. It is

Table 1 Relationship between bile salt secretion and biliary cholesterol output: effect of ioglycamide

\begin{tabular}{cllll}
\hline Patients & $\boldsymbol{r}$ & $\boldsymbol{p}$ & slope $\boldsymbol{m}$ & intercept $\boldsymbol{b}$ \\
\hline Controls & & & & \\
1 & 0.889 & $* * *$ & 0.174 & 0.360 \\
2 & 0.611 & NS & 0.027 & 1.892 \\
3 & 0.014 & NS & 0.002 & 2.356 \\
4 & 0.741 & $*$ & 0.045 & 0.512 \\
5 & 0.887 & $* * *$ & 0.090 & 0.276 \\
6 & 0.882 & $* * *$ & 0.025 & 2.036 \\
7 & 0.947 & $* * *$ & 0.064 & 1.209 \\
8 & 0.887 & $* * *$ & 0.036 & 1.786 \\
9 & 0.735 & $*$ & 0.011 & 1.906 \\
10 & 0.479 & NS & 0.015 & 1.814 \\
Mean \pm SEM & - & - & $0.048 \pm 0.016$ & 1.414 \\
& & & & $0.242 \dagger$ \\
Ioglycamide & & & & \\
1 & 0.939 & $* * *$ & 0.074 & -0.023 \\
2 & 0.527 & NS & 0.022 & 0.741 \\
3 & 0.817 & $* *$ & 0.032 & 0.490 \\
4 & 0.877 & $* *$ & 0.025 & 1.233 \\
5 & 0.763 & $*$ & 0.087 & -0.524 \\
6 & 0.940 & $* * *$ & 0.048 & 0.376 \\
7 & 0.985 & $* * *$ & 0.087 & 0.298 \\
8 & 0.897 & $* * *$ & 0.065 & 0.118 \\
9 & 0.742 & $*$ & 0.047 & 0.532 \\
10 & 0.576 & NS & 0.021 & 1.602 \\
11 & 0.925 & $* * *$ & 0.030 & 0.489 \\
Mean \pm SEM & - & - & $0.054 \pm 0.007$ & $0.533 \pm 0.170 \dagger$ \\
\hline
\end{tabular}

$\dagger=3.031 . \mathrm{P}<0.01$. structurally very similar to iodipamide (Biligrafin). The renal and hepatic handling of these two cholangiographic agents is probably very similar (Sperber and Sperber, 1971). Both compounds are actively transported into bile and are subject to a transport maximum (Miller et al., 1969; Burgener et al., 1970; Whitney and Bell, 1976; Bell et al., 1978b). Ioglycamide uses the same liver to bile transport system as many other organic anions including bilirubin and bromsulphthalein but not bile acids, the latter being secreted into bile by a separate mechanism (Sperber and Sperber, 1971).

We have shown that the biliary excretion of ioglycamide is associated with a significant choleresis which is independent of bile salt secretion. The choleresis is probably due to the obligatory coupling of the osmotically active contrast agent molecules with water as they are excreted into bile. The choleresis associated with the excretion of ioglycamide $(23.0 \mathrm{ml} / \mathrm{mol}$ ioglycamide $)$ is very similar to the values previously reported for iodipamide in the dog (Berk et al., 1976).

Our results show that, in man, bile salt secretion is not significantly affected by the simultaneous excretion of ioglycamide, thus confirming our previous findings in the rhesus monkey using iodipamide (Whitney and Bell, 1972). This finding was not unexpected, since bile salts probably have a separate transport mechanism within the hepatocyte (see above), and it is now well known that the choleresis produced by the administration of bile acids actually enhances rather than depresses the biliary excretion

Table 2 Effect of ioglycamide on $B S+P L / C$ ratio (mean $\pm S E M)$

\begin{tabular}{|c|c|c|c|c|c|c|c|c|c|c|c|c|c|c|}
\hline $\begin{array}{l}\text { Time in } \\
\text { minutes }\end{array}$ & Baseli & & 10 & 20 & 30 & 40 & 50 & 60 & 70 & 80 & 90 & 100 & 110 & 120 \\
\hline Controls & $\begin{array}{c}14.8 \\
\pm \\
1.6\end{array}$ & $\begin{array}{l}13 \cdot 6 \\
\pm \\
1 \cdot 7\end{array}$ & $\begin{array}{l}14.4 \\
\pm \\
1.7\end{array}$ & $\begin{array}{l}15 \cdot 1 \\
\pm \\
2 \cdot 0\end{array}$ & $\begin{array}{l}16 \cdot 2 \\
\pm \\
2 \cdot 2\end{array}$ & $\begin{array}{l}15 \cdot 7 \\
\pm \\
2 \cdot 1\end{array}$ & $\begin{array}{c}17 \cdot 3 \\
\pm \\
2 \cdot 4\end{array}$ & $\begin{array}{c}16.9 \\
\pm \\
2 \cdot 3\end{array}$ & $\begin{array}{c}15 \cdot 4 \\
\pm \\
2 \cdot 4\end{array}$ & $\begin{array}{c}14 \cdot 3 \\
\pm \\
2 \cdot 6\end{array}$ & $\begin{array}{c}11.9 \\
\pm \\
2.5\end{array}$ & $\begin{array}{c}10.9 \\
\pm \\
2.5\end{array}$ & $\begin{array}{c}9.4 \\
\pm \\
1.7\end{array}$ & $\begin{array}{c}8.4 \\
\pm \\
1.7\end{array}$ \\
\hline $\begin{array}{l}\text { Ioglycamide } \\
\text { treated }\end{array}$ & $\begin{array}{c}16.6 \\
\pm \\
1.9\end{array}$ & $\begin{array}{c}15 \cdot 3 \\
\pm \\
2.8\end{array}$ & $\begin{array}{c}15.4 \\
\pm \\
1.9\end{array}$ & $\begin{array}{c}16.7 \\
\pm \\
2 \cdot 3\end{array}$ & $\begin{array}{c}16.6 \\
\pm \\
1.5\end{array}$ & $\begin{array}{c}18.5 \\
\pm \\
1.6\end{array}$ & $\begin{array}{c}24.8 \\
\pm \\
4.3\end{array}$ & $\begin{array}{c}22.9 \\
\pm \\
2 \cdot 7\end{array}$ & $\begin{array}{c}20.9 \\
\pm \\
2.7\end{array}$ & $\begin{array}{c}18 \cdot 3 \\
\pm \\
2 \cdot 2\end{array}$ & $\begin{array}{c}14.1 \\
\pm \\
1.9\end{array}$ & $\begin{array}{c}14.5 \\
\pm \\
1.7\end{array}$ & $\begin{array}{l}12.5 \\
\pm \\
1.7\end{array}$ & $\begin{array}{c}10.2 \\
\pm \\
1.2\end{array}$ \\
\hline Statistical significance & NS & NS & NS & NS & NS & NS & NS & NS & NS & NS & NS & NS & NS & NS \\
\hline
\end{tabular}

Table 3 Effect of ioglycamide on $P L / C$ ratio (mean $\pm S E M$ )

\begin{tabular}{|c|c|c|c|c|c|c|c|c|c|c|c|c|c|c|}
\hline $\begin{array}{l}\text { Time in } \\
\text { minutes }\end{array}$ & Base & & 10 & 20 & 30 & 40 & 50 & 60 & 70 & 80 & 90 & 100 & 110 & 120 \\
\hline Controls & $\begin{array}{l}3 \cdot 4 \\
\pm \\
0 \cdot 3\end{array}$ & $\begin{array}{l}3 \cdot 1 \\
\pm \\
0 \cdot 2\end{array}$ & $\begin{array}{l}3.2 \\
\pm \\
0 \cdot 2\end{array}$ & $\begin{array}{l}3 \cdot 3 \\
\pm \\
0 \cdot 2\end{array}$ & $\begin{array}{l}3 \cdot 3 \\
\pm \\
0 \cdot 2\end{array}$ & $\begin{array}{l}3 \cdot 2 \\
\pm \\
0 \cdot 2\end{array}$ & $\begin{array}{l}3 \cdot 5 \\
\pm \\
0 \cdot 2\end{array}$ & $\begin{array}{l}3 \cdot 5 \\
\pm \\
0 \cdot 3\end{array}$ & $\begin{array}{l}3.4 \\
\pm \\
0.3\end{array}$ & $\begin{array}{l}\mathbf{3 \cdot 3} \\
\pm \\
\mathbf{0} \cdot 2\end{array}$ & $\begin{array}{l}2.9 \\
\pm \\
0.2\end{array}$ & $\begin{array}{l}2 \cdot 9 \\
\pm \\
0 \cdot 3\end{array}$ & $\begin{array}{l}2 \cdot 6 \\
\pm \\
0 \cdot 2\end{array}$ & $\begin{array}{l}2.6 \\
\pm \\
0.3\end{array}$ \\
\hline $\begin{array}{l}\text { Ioglycamide } \\
\text { treated }\end{array}$ & $\begin{array}{l}3.0 \\
\pm \\
0.3\end{array}$ & $\begin{array}{l}2.8 \\
\pm \\
0.2\end{array}$ & $\begin{array}{l}2 \cdot 5 \\
\pm \\
0 \cdot 2\end{array}$ & $\begin{array}{l}2 \cdot 5 \\
\pm \\
0 \cdot 2\end{array}$ & $\begin{array}{l}2 \cdot 2 \\
\pm \\
0 \cdot 1\end{array}$ & $\begin{array}{l}2 \cdot 3 \\
\pm \\
0 \cdot 2\end{array}$ & $\begin{array}{l}2 \cdot 7 \\
\pm \\
0.4\end{array}$ & $\begin{array}{l}2.6 \\
\pm \\
0.3\end{array}$ & $\begin{array}{c}2 \cdot 6 \\
\pm \\
0 \cdot 3\end{array}$ & $\begin{array}{c}2 \cdot 3 \\
\pm \\
0 \cdot 3\end{array}$ & $\begin{array}{l}2 \cdot 1 \\
\pm \\
0 \cdot 3\end{array}$ & $\begin{array}{l}2 \cdot 2 \\
\pm \\
0 \cdot 3\end{array}$ & $\begin{array}{l}2.0 \\
\pm \\
0.3\end{array}$ & $\begin{array}{l}1.5 \\
\pm \\
0.3\end{array}$ \\
\hline Statistical significance & NS & NS & $*$ & $* *$ & $* * *$ & $* *$ & NS & $*$ & NS & $*$ & NS & NS & NS & $* *$ \\
\hline
\end{tabular}


of a number of anionic dyes including bromsulphthalein (O'Maille et al., 1966) and ioglycamide (Behan et al., 1977).

Since ioglycamide did not affect bile salt secretion, we must conclude that the significant reduction in the output of biliary phospholipid and cholesterol observed during the ioglycamide experiments was independent of bile acids. Erlinger et al. (1975) have shown that lysine acetylsalicylate stimulates bile salt independent bile flow and depresses biliary phospholipid and cholesterol secretion in the dog. They postulated that other canalicular bile acid independent choleretics should similarly depress biliary cholesterol secretion simply as a result of their diluting canalicular bile and reducing micellar bile acid concentration (Erlinger et al., 1975). Whether or not this is the mechanism involved in the present set of ioglycamide experiments is not known.

There was a significant correlation between bile salt and biliary cholesterol output in both the control group and the ioglycamide treated patients. The mean cholesterol excretory rate in the control group of $0.048 \mu \mathrm{mol} / \mu \mathrm{mol}$ of bile acid was very similar to the previous reported value of $0.051 \mu \mathrm{mol} / \mu \mathrm{mol}$ of bile acid (Schersten et al., 1971). Similarly, the positive $y$ intercept $b$ on our control group of $1.414 \mu \mathrm{mol}$ cholesterol per minute was very similar to the value of $1.49 \mu \mathrm{mol}$ cholesterol per minute found by the same group (Schersten et al., 1971). The slope of the regression line relating biliary cholesterol to bile acid output was unchanged by ioglycamide. When, however, the regression line was extrapolated back to zero bile salt secretion, the mean positive y intercept $b$ of $0.533 \mu \mathrm{mol}$ cholesterol per minute was significantly $(t=3.03, \mathrm{P}<0.01)$ lower than that of the control group.

Chenodeoxycholic acid exerts its cholesterol lowering effect by altering the slope of the regression line relating cholesterol and bile acid output but does not affect bile acid independent cholesterol secretion (Northfield et al., 1975). Thus, the mechanism by which ioglycamide lowers biliary cholesterol excretion is quite different from chenodeoxycholic acid, as bile acid independent cholesterol secretion is significantly reduced but the cholesterol secretion rate in terms of $\mu \mathrm{mol}$ per $\mu \mathrm{mol}$ of bile acid was unaltered.

Ioglycamide, again unlike chenodeoxycholic acid, also significantly reduced biliary phospholipid output. The ratio of phospholipid/cholesterol fell significantly during ioglycamide infusion at a time when bile salt secretion was unaffected (Table 3). This is of interest, as Wheeler and King (1972) had previously found a fixed ratio of phospholipid/cholesterol in bile over a wide range of bile salt secretion rates, and concluded that the secretion of the two lipids in response to bile acids was closely coupled. Other evidence (Smallwood and Hoffmann, 1976), like our own, suggests that biliary cholesterol and phospholipid secretion may be influenced independently.

$$
\text { The rise in the } \frac{\mathrm{BS}+\mathrm{PL}}{\mathrm{C}} \text { ratio-the so-called }
$$

'cholesterol solubilizing capacity' of bile (Isaksson, 1954) - noted during ioglycamide excretion is of particular interest, as one might, on physicochemical grounds, predict that such bile would be capable of dissolving cholesterol gallstones (Bell, 1974). Ioglycamide might therefore prove to be a prototype for the future development of an orally administered drug for dissolving cholesterol gallstones.

This work was in part supported by a grant from Schering (AG) Limited. Financial support from the Joint Research Board of St. Bartholomew's Hospital and the Dowager Duchess Peel Memorial Fund is also gratefully acknowledged. One of us (G.D.B.) was in receipt of a grant from the Mackenzie Mackinnon Streitfield Research Fellowship. The authors are grateful to Dr A. M. Dawson for his help and encouragement, and also to Professor M. J. S. Langman for statistical advice.

\section{References}

Admirand, W. H., and Small, D. M. (1968). The physicochemical basis of cholesterol gallstone formation in man. Journal of Clinical Investigation, 47, 1043-1052.

Bartlett, G. R. (1959). Phosphorus assay in column chromatography. Journal of Biological Chemistry, 234, 466-468.

Behan, M., Mok, H. Y. I., Bell, G. D., and Whitney, B. P. (1977). The concentration maximum concept in intravenous cholangiography. British Journal of Radiology, 50, 551-554.

Bell, G. D. (1974). The present position concerning gallstone dissolution. Gut, 15, 913-929.

Bell, G. D., Fayadh, M., Frank, J., McMullin, J., and Kelsey Fry, I. (1978a). Ioglycamide (Biligram) studies in Man. I-Relationship between plasma concentration and biliary excretion. British Journal of Radiology, 51, 111-115.

Bell, G. D., McMullin, J., Oliver, J., and McAlister, J. (1978b). A simple spectrophotometric method for measuring biliary ioglycamide (Biligram) concentration. British Journal of Radiology, 51, 17-19.

Bell, G. D., White, J., and Dowling, R. H. (1972a). The physical processing of bile samples prior to biliary lipid analysis. A comparison of the results obtained by a number of different methods. In Bile Acids in Human Diseases. Edited by P. Back and W. Gerok. Schattauer: Stuttgart.

Bell, G. D., Whitney, B., and Dowling, R. H. (1972b). Gallstone dissolution in man using chenodeoxycholic acid. Lancet, 2, 1213-1216.

Berk, R. N., Loeb, P. M., Cobo-Frenkel, A., and Barnhart, J. L. (1976). Saturation kinetics and choleretic effects of iodoxamate and iodipamide; an experimental study in dogs. Radiology, 119, 529-535.

Burgener, F., Halpern, A., Miller, G., Hoenig, V., Preisig, R., and Fuchs, W. (1970). Die Infusionscholangiographie bei ikterischen Patienten. Radiologia Clinica et Biologica, 39, 175-176. 
Danzinger, R. C., Hofmann, A. F., Schoenfield, L. J., and Thistle, J. L. (1972). Dissolution of cholesterol gallstones by chenodeoxycholic acid. New England Journal of Medicine, 286, 1-8.

Dowling, R. H., Mack, E., and Small, D. M. (1971). Biliary lipid secretion and bile composition after acute and chronic interruption of the enterohepatic circulation in the Rhesus money. IV-Primate biliary physiology. Journal of Clinical Investigation, 50, 1917-1926.

Entenman, C., Holloway, R. J., Albright, M. L., and Leong, G. F. (1969). Bile acids and lipid metabolism. IIEssential role of bile acids in bile phospholipid excretion. Archives of Biochemistry and Biophysics, 130, 253-256.

Erlinger, S., Bienfait, D., Poupon, R., Dumont, M., and Duval, M. (1975). Effect of lysine acetylsalicylate on biliary lipid secretion in dogs. Clinical Science and Molecular Medicine, 49, 253-256.

Grundy, S. M., Metzger, A. L., and Adler, R. D. (1972). Mechanisms of lithogenic bile formation in American Indian women with cholesterol gallstones. Journal of Clinical Investigation, 51, 3026-3043.

Hardison, W. G. M., and Francis, T. I. (1969). The mechanism of cholesterol and phospholipid excretion in bile. Gastroenterology, 56, 1164. (Abstract.)

Isaksson, B. (1954). On the dissolving power of lecithin and bile salts for cholesterol in human bladder bile. Acta Societatis Medicorum (Upsaliensis), 59, 296-306.

Miller, G., Fuchs, W. A., and Preisig, R. (1969). Die infusionscholangiographie in physiologischer Sicht. Schweizerische Medizinische Wochenshrift, 99, 577-581.

Nilsson, S., and Schersten, T. (1970). Influence of bile acids on the synthesis of biliary phospholipids in man. European Journal of Clinical Investigation, 1, 109-111.

Northfield, T. C., and Hofmann, A. F. (1973). Biliary lipid secretion in gallstone patients. Lancet, 1, 747-748.

Northfield, T. C., La Russo, N. F., Hof nann, A. F., and Thistle, J. L. (1975). Biliary lipid output during three meals and an overnight fast. II-Effects of chenodeoxycholic acid treatment in gallstone sub;ects. Gut, 16, 12-17.

O'Maille, E. R. L., Richards, T. G., and Short, A. H. (1966). Factors determining the maximal rate of organic anion secretion by the liver and further evidence on the hepatic site of action of the hormone secretin. Journal of Physiology, 186, 424-438.

Roda, A., Festi, D., Sama, C., Mazzella, G , Aldini, R., Roda, E., and Barbara, L. (1975). Enzymatic determination of cholesterol in bile. Clinica Chimica Acta, 64, 337-341.

Schersten, T., Nilsson, S., Cahlin, E., Filipson, M., and Brodin-Persson, G. (1971). Relationship between the biliary excretion of bile acids and the excretion of water, lecithin, and cholesterol in man. European Journal of Clinical Investigation, 1, 242-247.

Small, D. M. (1970). The formation of gallstones Advances in Internal Medicine, 16, 243-264.

Smallwood, R. A., and Hoffman, N. E. (1976). Bile acid structure and biliary secretion of cholesterol and phospholipid in the cat. Gastroenterology, 71, 1064-1066.

Sperber, I., and Sperber, G. (1971). Hepatic excretion of radio-contrast agents. In Radiocontrast Agents (International Encyclopaedia of Pharmacology and Therupeutics, Sect. 76). Vol. 1 ; pp. 165-235. Edited by P. Knoefel. Pergamon Press: Oxford.

Swell, L., Bell, C. C. Jr., and Entenman, C. (1968). Bile acids and lipid metabolism. III-Influence of bile acids on phospholipids in liver and bile of the isolated perfused dog liver. Biochimica et Biophysica Acta, 164, 278-284.

Talalay, P. (1960). Enzymatic analysis of steroid hormones. Methods of Biochemical Analysis, 8, 119-143.

Wheeler, H. O., and King, K. K. (1972). Biliary excretion of lecithin and cholesterol in the dog. Journal of Clinical Investigation, 51, 1337-1350.

Whitney, B., and Bell, G. D. (1972). Single bolus injection or slow infusion for intravenous cholangiography? Measurement of iodipamide (Biligrafin) excretion using a rhesus monkey model. British Journal of Radiology, 45, 891-895.

Whitney, B. P., and Bell, G. D. (1976). Levels of ioglycamide (Biligram) in the bile of the rhesus monkey following intravenous infusion at different dose rates. British Journal of Radiology, 49, 118-122.

Young, D. L. (1971). The role of micelle-forming properties of bile salts in lipid secretion into bile. Journal of Clinical Investigation, 50, $101 \mathrm{~A}$ (abstract). 